Willingness to Pay.... (Saputri)

\title{
WILLINGNESS TO PAY MAHASISWA FE UNY 2014-2017 TERHADAP MAKANAN BERLABEL HALAL
}

\author{
Lely Diana Sari Saputri \\ Universitas Negeri Yogyakarta, Indonesia \\ lelydss@gmail.com
}

\begin{abstract}
Abstrak: Penelitian ini bertujuan untuk mengetahui pengaruh pendapatan, pengalaman mengkonsumsi, dan kesadaran kehalalan mahasiswa secara parsial dan simultan terhadap Willingness To Pay/WTP mie samyang berlabel halal LPPOM MUI. Sampel dalam penelitian ini sejumlah 96 Mahasiswa FE UNY. Metode pengumpulan data yang digunakan adalah kuesioner. Teknik analisis menggunakan regresi ganda dan contingent valuation method. Hasil penelitian menunjukkan secara parsial variabel pendapatan dan pengalaman mengkonsumsi berpengaruh positif terhadap WTP mie samyang berlabel halal LPPOM MUI, namun kesadaran kehalalan berpengaruh negatif terhadap WTP mie samyang berlabel halal LPPOM MUI. Hasil pengujian secara simultan menunjukkan bahwa ketiga variabel berpengaruh signifikan terhadap WTP mie samyang berlabel halal LPPOM MUI. Perubahan yang terjadi pada variabel WTP dapat dijelaskan oleh variabel bebas dalam penelitian ini sebesar 58,9\%. Hasil analisis nilai WTP menunjukkan mayoritas responden bersedia membayar sebesar Rp 15.000,00.
\end{abstract}

Kata Kunci: Pendapatan, Pengalaman Mengkonsumsi, Kesadaran Kehalalan, Willingness to Pay

\section{THE WILLINGNESS TO PAY OF THE 2014-2017 ADMISSION YEAR STUDENTS OF THE FE UNY FOR HALAL FOOD}

\begin{abstract}
This study aims to find out the effects of the income, consuming experience, and awareness of being halal among the 2014-2017 admission year students of the Faculty of Economics (FE), Yogyakarta State University (YSU), partially and simultaneously, on the Willingness to Pay (WTP) for samyang noodle halal certified by LPPOM MUI. The research sample consisted of 96 students, selected using the Slovin formula. The data were collected by a questionnaire. The data analysis technique was the OLS multiple regression. In addition, the WTP value was analyzed by the contingent valuation method. The results of the study showed that partially the variables of the income and consuming experience have significant positive effects on the WTP for samyang noodle halal certified by LPPOM MUI. However, the awareness of being halal has a significant negative effect on the WTP for samyang noodle halal certified by LPPOM MUI. The result of the simultaneous test indicates that the three variables significantly affect the WTP for samyang noodle halal certified by LPPOM MUI. The change that occurs in the variable of the WTP that can be explained by the independent variables in this study is $58.9 \%$. The result of the WTP value analysis shows that the majority of respondents are willing to pay by $\mathrm{Rp} 15,000.00$.
\end{abstract}

Keywords: Income, Consuming Experience, Awareness of Being Halal, Willingness to Pay

\section{PENDAHULUAN}

Menurut data yang disusun WINA (World Instant Noodles Association), Indonesia merupakan negara dengan global demand mie instan terbanyak kedua di dunia. Mie instan merupakan kategori yang memiliki jumlah pembeli yang sangat besar dan paling sering dibeli oleh konsumen di Indonesia yaitu hampir dua kali dalam seminggu. Berdasarkan hasil studi yang dilakukan oleh MARS Indonesia pada tahun 2016 tentang Profil Konsumsi Produk Makanan, tingkat konsumsi mie instan terbesar adalah kalangan remaja berusia 15-24 tahun, yaitu sebesar 95,6\%. Belakangan ini, banyak produk makanan kemasan luar negeri yang populer di Indonesia. Salah satunya adalah mie samyang yang banyak digemari oleh remaja Indonesia. Berkembangnya kebudayaan Korea Selatan seperti musik, drama, reality show, gaya berpakaian, kosmetik, dan makanan khasnya menyebabkan remaja Indonesia menggemari mie samyang tersebut. Salah satu market place 
Indonesia, elevenia mencatat, dalam satu hari (11/10), transaksi jual-beli mi samyang mencapai angka penjualan 9.210 bungkus mi. Besarnya permintaan terhadap mie samyang tersebut juga didorong oleh fenomena Samyang Noodle Challenge yang semakin berkembang di Indonesia.

Minat masyarakat Indonesia yang tinggi akan mie samyang ini mendorong produsen dan importir mie samyang mulai banyak hadir di Indonesia. Salah satu produk mie samyang yang beredar di Indonesia yaitu mie instan dari PT Korinus. Permintaan yang tinggi akan mie instan ini pun mendorong banyak penjual untuk menjual produk yang belum jelas kehalalannya seperti yang terjadi di Sumenep Jawa Timur dan OKU Timur. Produk makanan yang tidak diketahui kehalalannya tentu saja mencemaskan bagi konsumen muslim, sebab produk yang belum memiliki label halal bisa saja memiliki kandungan babi, seperti yang telah ditemukan pada mie samyang di Sumenep. Daging babi yang terkandung dalam mie Samyang tentu sangat berbahaya jika dikonsumsi oleh tubuh sebab daging babi mengandung cacing Trichinella spiralis. Penemuan kandungan babi dalam samyang tersebut tentunya meresahkan bagi masyarakat Indonesia mengingat tingginya tingkat konsumsi masyarakat terhadap produk mie instan dan mayoritas penduduk beragama Islam. Menurut catatan Pew Research Center, dari 205 juta penduduk Indonesia ditahun 2010 sedikitnya 88 persen beragama Islam. Oleh karena itu, PT Korinus mengajukan sertifikasi halal kepada MUI Indonesia. Pada tanggal 28 September 2017, PT Korinus telah mendapatkan sertifikat halal untuk produk samyang yang diimpor. Namun, produk samyang yang beredar masih banyak yang tidak memiliki label halal dan ada pula produk yang memiliki label halal namun hanya berupa stiker dan tidak disertai nomor sertifikat halal dari LPPOM MUI.

Penelitian mengenai Willingness to Pay pada produk halal telah banyak dilaksanakan. Namun, dari beberapa penelitian tersebut terdapat pengaruh yang berbeda-beda dari setiap variabel. Seperti penelitian yang dilakukan oleh Kamaruddin et. al (2012) yang bertujuan untuk meneliti tentang kesediaan membayar responden akan produk makanan halal. Dalam penelitian ini, variabel yang mempengaruhi signifikan besaran WTP adalah variabel status dalam rumah tangga dalam hal ini responden ibu, variabel pendapatan rumah tangga, dan variabel biaya. Sedangkan variabel kesadaran kehalalan tidak mempengaruhi secara signifikan.

Serta dalam penelitian Nuriana (2013) untuk meneliti karakteristik konsumen pengguna produk kosmetik Wardah, menganalisis faktor-faktor yang mempengaruhi, dan menghitung besarnya willingness to pay (WTP) responden terhadap pembayaran tambahan sertifikasi halal pada produk Wardah. Hasil penelitian menunjukkan bahwa variabel yang mempengaruhi secara signifikan kesediaan membayar tambahan terhadap sertifikasi halal adalah variabel tingkat pendidikan dan intensitas responden dalam mengamati label halal pada kemasan produk kosmetik, sedangkan variabel tingkat pendapatan serta variabel kesadaran tidak mempengaruhi secara signifikan kesediaan membayar sertifikasi halal kosmetik.

Namun, dalam penelitian Putri (2016) yang bertujuan untuk mengidentifikasi tingkat kesadaran masyarakat akan pentingnya daging ayam bersertifikat halal, mengestimasi nilai WTP yang bersedia dibayarkan masyarakat pada daging ayam bersertifikat halal, menganalisis variabel pendapatan rumah tangga per bulan, tingkat pendidikan, usia, konsumsi daging ayam, kesadaran kehalalan, dan jumlah anggota keluarga mempengaruhi besaran nilai kesediaan membayar. Variabel yang berpengaruh terhadap kemauan bayar responden antara lain adalah: variabel pendapatan, pendidikan, konsumsi daging ayam, faktor kesadaran mempengaruhi secara positif dan signifikan terhadap variabel kemauan bayar konsumen. Variabel usia mempengaruhi signifikan dengan bertanda negatif.

Dengan adanya berbagai perbedaan mengenai pengaruh beberapa faktor terhadap besaran nilai kesediaan membayar konsumen pada produk halal, maka peneliti mencoba untuk meneliti 
kembali pengaruh beberapa variabel yaitu pendapatan atau uang saku mahasiswa per bulan, pengalaman mengkonsumsi, dan kesadaran kehalalan terhadap WTP mie samyang berlabel halal LPPOM MUI serta seberapa besar WTP konsumen terhadap suatu produk bila sudah dinyatakan halal oleh lembaga berwenang di Indonesia. Penelitian mengenai willingness to pay mie samyang berlabel halal LPPOM MUI ini dilaksanakan di Fakultas Ekonomi Universitas Negeri Yogyakarta sebab budaya Korea Selatan semakin berkembang di kalangan remaja serta semakin viralnya fenomena Samyang Noodle Challenge. Mahasiswa yang sebagian adalah anak kos cenderung mencari cara instan untuk memuaskan rasa laparnya dan yang sering menjadi pilihan pertama adalah mie instan. Mie instan menjadi pilihan mahasiswa karena mudah didapat, mudah membuatnya, dan harganya terjangkau oleh mahasiswa. Mahasiswa juga termasuk pengguna aktif dari media sosial dan tentu saja mengetahui informasi terkini dari Samyang Noodle Challenge yang sedang viral dari internet (Ekawati, 2012). Dengan banyaknya informasi mengenai fenomena tersebut, tidak jarang mahasiswa terdorong untuk mencoba mie samyang walaupun harga dari mie instan ini jauh lebih mahal dari mie instan yang ada di Indonesia. Berdasarkan penjelasan tersebut, peneliti tertarik untuk membuat penelitian berjudul "Willingness to Pay Mahasiswa Fakultas Ekonomi Universitas Negeri Yogyakarta Tahun Angkatan 2014-2017 terhadap Mie Samyang Berlabel Halal LPPOM MUI".

\section{METODE}

Willingness to pay konsumen terhadap mie samyang berlabel halal merupakan penelitian yang menggunakan pendekatan kuantitatif. Penelitian ini menggunakan data primer yang diperoleh dari responden melalui kuesioner yang akan di bagikan pada mahasiswa muslim S1 di Fakultas Ekonomi Universitas Negeri Yogyakarta. Dalam suatu penelitian kuantitatif, analisis data merupakan kegiatan setelah data dari lapangan terkumpul. Pada penelitian ini dilakukan analisis deskriptif, analisis hipotesis, dan analisis nilai WTP. Analisis deskriptif menyajikan mean, median, modus, dan tabel distribusi kecenderungan yang dibagi menjadi empat kategori. Menurut Djemari Mardapi, empat kategori tersebut yaitu sangat tinggi, tinggi, rendah, dan sangat rendah. Metode analisis data yang digunakan adalah analisis regresi ganda dengan pendekatan Ordinary Least Square yang diolah menggunakan SPSS 15 for Windows. Selain itu, dilakukan pula analisis nilai WTP dengan metode Contingent Valuation Method. Sebelum melakukan analisis regresi ganda dengan pendekatan OLS, dilakukan pengujian prasyarat analisis dengan uji multikolinearitas, heterosedastisitas, dan normalitas. Persamaan garis regresi dalam penelitian ini adalah sebagai berikut:

Keterangan:

$$
Y=a+b_{1} X_{1}+b_{2} X_{2}+b_{3} X_{3}
$$

$\mathrm{Y}=$ Willingness to Pay

$\mathrm{a} \quad=$ bilangan konstanta

$b_{1}=$ koefisien korelasi pendapatan

$X_{1}=$ pendapatan

$b_{2}=$ koefisien korelasi pengalaman mengkonsumsi

$X_{2}$ = pengalaman mengkonsumsi (Pernah mengkonsumsi=1, Tidak pernah mengkonsumsi=0)

$b_{3}=$ koefisien korelasi kesadaran kehalalan

$X_{3}=$ kesadaran kehalalan 


\section{HASIL DAN PEMBAHASAN}

Analisis willingness to pay mie samyang berlabel halal LPPOM MUI pada mahasiswa FE UNY tahun angkatan 2014-2017 dilakukan dengan pendekatan Contingent Valuation Method (CVM). Menurut Fauzi (2004), pendekatan CVM terdiri atas 5 langkah yaitu membuat hipotesis pasar, mendapatkan nilai lelang, menghitung rataan WTP, memperkirakan kurva lelang, dan mengagregatkan data. Pada langkah pertama, peneliti memberikan informasi kepada responden mengenai peredaran mie samyang yang belum semua produknya belabel halal resmi LPPOM MUI. Masih banyak produk mie samyang tanpa label halal LPPOM MUI dan berlabel halal berupa stiker yang tidak disertai nomor sertifikat halal LPPOM MUI. Produsen di asumsikan telah mencantumkan label halal resmi LPPOM MUI untuk produk mie samyang. Sehingga mie samyang yang dijual ke konsumen telah memiliki jaminan halal dan tidak mengadung unsur babi dari proses produksi hingga distribusi sampai ke tangan konsumen.

Tahap kedua yang dilakukan yaitu mendapatkan nilai lelang. Nilai lelang didapatkan dengan teknik closed-ended question. Berdasarkan pertanyaan mengenai harga yang bersedia responden bayarkan untuk mie samyang berlabel halal LPPOM MUI, mayoritas responden bersedia untuk membayar Rp 15.000,00 untuk satu bungkus mie samyang berlabel halal LPPOM MUI. Tahap selanjutnya yaitu menghitung rataan WTP. Dugaan nilai rata-rata WTP responden diperoleh berdasarkan rasio jumlah nilai WTP yang diberikan responden dengan jumlah total responden yang bersedia membayar.

Tabel 1. Distribusi nilai WTP responden

\begin{tabular}{ccccc}
\hline No. & $\begin{array}{c}\text { WTP } \\
(\text { Rp })\end{array}$ & $\begin{array}{c}\text { Jumlah Responden } \\
\text { (Orang) }\end{array}$ & Presentase & $\begin{array}{c}\text { WTP x Jumlah Responden } \\
(\text { Rp })\end{array}$ \\
\hline 1. & Rp15.000 & 39 & 40,63 & Rp585.000 \\
2. & Rp20.000 & 26 & 27,08 & Rp520.000 \\
3. & Rp25.000 & 20 & 20,83 & Rp500.000 \\
4. & Rp30.000 & 10 & 10,42 & Rp300.000 \\
5. & Rp35.000 & 1 & 1,04 & Rp35.000 \\
& Total & 96 & 100,00 & Rp 1.940 .000 \\
\hline
\end{tabular}

Berdasarkan tabel 1, diperoleh nilai rata-rata WTP responden sebesar Rp 20.208,33,- yang dibulatkan menjadi Rp 20.300,-. Nilai rata-rata WTP responden tersebut dapat dijadikan sebagai acuan bagi Produsen dalam menentukan harga jual mie samyang berlabel halal LPPOM MUI.

Tahap ke empat yaitu memperkirakan kurva lelang. Pendugaan kurva WTP responden diperoleh dengan menggunakan jumlah kumulatif dari individu yang memilih suatu nilai WTP. Kurva WTP pada Gambar 1 memiliki kemiringan negatif atau bergerak dari kiri atas ke kanan bawah. Hal ini menunjukkan bertambahnya jumlah responden yang bersedia membayar untuk mie samyang berlabel halal LPPOM MUI. Artinya, bila harga mie samyang turun, maka akan semakin banyak jumlah responden yang bersedia membayar untuk mie samyang berlabel halal LPPOM MUI atau sebaliknya.

Tahap terakhir yaitu mengagregatkan data. Agregasi dari total WTP adalah nilai keseluruhan dari nilai yang bersedia dibayarkan oleh seluruh responden dalam penelitian. Agregasi WTP didapatkan dengan menggunakan nilai rata-rata WTP yang dikonversikan terhadap populasi responden. Hasil perhitungan agregasi WTP yaitu Rp 33.312 .300 (Rp 20.300 x 1641).

Setelah nilai WTP didapatkan, selanjutnya dilakukan pengujian regresi ganda dengan pendekatan OLS untuk mengetahui variabel apa saja yang berpengaruh terhadap willingness to pay 
mie samyang berlabel halal LPPOM MUI. Pengujian prasyarat analisis dilakukan sebelum melakukan uji regresi ganda dengan pendekatan OLS. Hasil uji normalitas pada penelitian ini menggunakan uji Kolmogorov-Smirnov. Data berdistribusi normal jika nilai Asymp. Sig (2-tailed) yang diperoleh lebih dari atau sama dengan 0,05 (Muhson, 2016: 39).

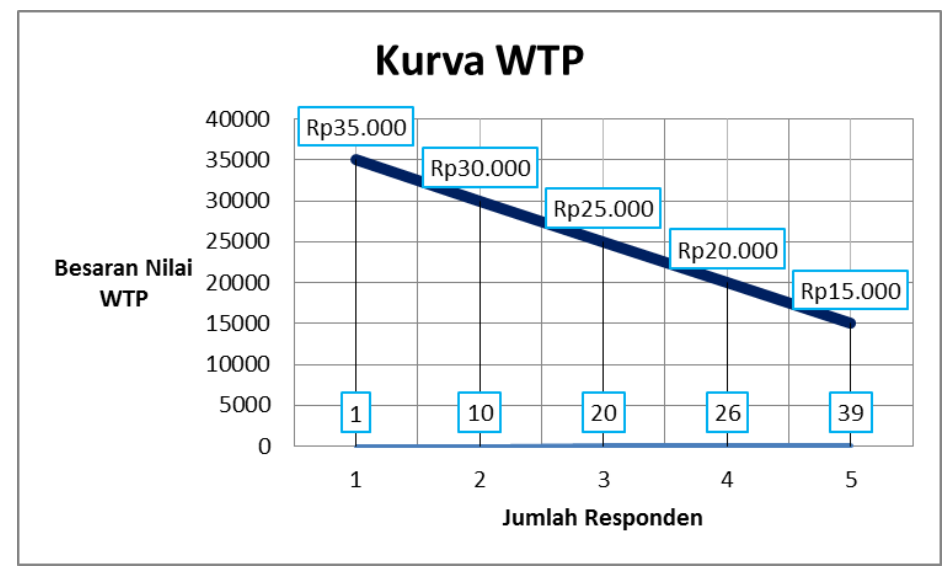

Gambar 1. Kurva WTP Mie Samyang Berlabel Halal LPPOM MUI

Berdasarkan hasil penelitian diketahui bahwa variabel pendapatan, pengalaman mengkonsumsi, kesadaran kehalalan, dan willingness to pay mempunyai nilai Asymp. Sig. (2-tailed) lebih besar dari 0,05 maka dapat disimpulkan bahwa semua variabel dalam penelitian ini berdistribusi normal.

Selanjutnya, dilakukan uji multikolinearitas dan heterosedastisitas. Uji multikolinearitas digunakan untuk mengetahui apakah terjadi hubungan linear yang sempurna diantara beberapa atau semua variabel bebas. Untuk menguji ada tidaknya multikolinearitas menggunakan uji VIF. Model regresi yang baik mensyaratkan tidak adanya masalah multikolinearitas. Apabila nilai VIF kurang dari 4 maka tidak terjadi multikolinearitas (Muhson, 2016: 45).

Berdasarkan hasil penelitian, dapat disimpulkan bahwa antar variabel bebas tidak terjadi multikolinearitas karena nilai VIF kurang dari 4. Uji prasyarat terakhir yaitu uji heterosedastisitas. Uji heterosedastisitas digunakan untuk mengetahui ada atau tidaknya ketidaksamaan varian dari residual untuk semua pengamatan pada model regresi. Model regresi yang baik mensyaratkan tidak adanya masalah gejala heterosedastisitas. Apabila nilai sign. F lebih dari atau sama dengan 0,05 maka tidak terjadi heterosedastisitas (Muhson, 2016: 52).

Berdasarkan hasil penelitian diketahui bahwa semua variabel mempunyai nilai signifikansi sama dengan 0,05 sehingga dapat disimpulkan bahwa model regresi pada penelitian ini tidak terjadi heterosedastisitas. Karena ketiga uji prasyarat telah memenuhi, maka analisis regresi ganda dapat dilakukan. Uji regresi ganda dengan pendekatan OLS digunakan untuk mengetahui pengaruh secara parsial dan simultan dari variabel pendapatan, pengalaman mengkonsumsi, dan kesadaran kehalalan terhadap willingness to pay mie samyang berlabel halal LPPOM MUI.

Persamaan garis regresi ganda menunjukkan $Y=16,824+0,012 \mathrm{X}_{1}+2,194 \mathrm{X}_{2}-0,164 \mathrm{X}_{3}$. Dari persamaan tersebut menujukkan bahwa nilai konstanta sebesar 16,824 yang dapat diartikan apabila variabel pendapatan, pengalaman mengkonsumsi, dan kesadaran kehalalan dianggap nol atau tidak mengalami perubahan, maka willingness to pay sebesar 16,824. Ditemukan pula nilai koefisien variabel $\mathrm{X}_{1}$ sebesar 0,012 artinya setiap perubahan variabel pendapatan sebesar satu satuan maka akan mengakibatkan perubahan willingness to pay sebesar 0,012 satuan, begitu pula sebaliknya 
bila terjadi penurunan satu satuan pada variabel pendapatan maka akan menurunkan willingness to pay sebesar 0,012 satuan dengan asumsi-asumsi yang lain adalah tetap. Variabel $\mathrm{X}_{2}$ memiliki nilai koefisien sebesar 2,194 artinya setiap perubahan variabel pengalaman mengkonsumsi sebesar satu satuan maka akan mengakibatkan perubahan willingness to pay sebesar 2,194 satuan dan sebaliknya. Variabel $\mathrm{X}_{3}$ memiliki nilai koefisien sebesar -0,164 artinya setiap kenaikan kesadaran kehalalan satu satuan maka akan menurunkan willingness to pay sebesar 0,164 dan sebaliknya.

Tabel 2. Hasil Analisis Regresi

\begin{tabular}{lcccc}
\hline \multicolumn{1}{c}{ Variabel } & $\begin{array}{c}\text { Koef. Regresi } \\
(\mathrm{b})\end{array}$ & t hitung & Sig. & Kesimpulan \\
\hline Pendapatan atau uang saku per bulan & 0,012 & 8,674 & 0,000 & Signifikan \\
$\left(\mathrm{X}_{1}\right)$ & 2,194 & 2,514 & 0,014 & Signifikan \\
Pengalaman mengkonsumsi $\left(\mathrm{X}_{2}\right)$ & $-0,164$ & $-2,207$ & 0,030 & Signifikan \\
Kesadaran kehalalan $\left(\mathrm{X}_{3}\right)$ & \multicolumn{5}{c}{16,824} \\
\hline Konstanta & 0,767 \\
\hline $\mathrm{R}$ & \multicolumn{5}{c}{0,589} \\
\hline$R^{2}$ & \multicolumn{5}{c}{43,921} \\
\hline F hitung & 0,000 \\
\hline Sig.
\end{tabular}

Selanjutnya, untuk mengetahui apakah hipotesis yang diajukan dalam penelitian ini diterima atau ditolak maka akan dilakukan pengujian hipotesis dengan menggunakan uji $\mathrm{t}$ dan uji $\mathrm{F}$. Uji $\mathrm{t}$ merupakan pengujian untuk menunjukkan pengaruh secara individu variabel bebas terhadap variabel terikat. Apabila nilai sig. $t_{\text {hitung }} \leq 0,05$ maka dapat disimpulkan bahwa variabel bebas secara parsial berpengaruh signifikan terhadap variabel terikat. Hasil uji t pada masing-masing variabel pendapatan, pengalaman mengkonsumsi, dan kesadaran kehalalan menunjukkan signifikansi kurang dari 0,05, maka ketiga variabel berpengaruh secara parsial terhadap willingness to pay mie samyang berlabel halal LPPOM MUI.

Uji $\mathrm{F}$ atau uji simultan bertujuan untuk mengetahui apakah variabel bebas secara bersamasama berpengaruh terhadap variabel terikat. Berdasarkan hasil perhitungan secara simultan pengaruh pendapatan, pengalaman mengkonsumsi, dan kesadaran kehalalan terhadap willingness to pay mie samyang berlabel halal LPPOM MUI pada taraf signifikansi $5 \%$ diperoleh nilai $F_{\text {hitung }}$ sebesar 43,921 dengan nilai signifikansi $F$ sebesar 0,000. Karena nilai signifikansi F kurang dari 0,05 maka variabel pendapatan, pengalaman mengkonsumsi, dan kesadaran kehalalan secara bersamasama mempunyai pengaruh yang signifikan terhadap willingness to pay mie samyang berlabel halal LPPOM MUI.

Berdasarkan hasil analisis regresi yang telah dilakukan, diketahui nilai koefisien determinasi $\left(R^{2}\right)$ sebesar 0,589 atau $58,9 \%$. Nilai tersebut menunjukkan bahwa $58,9 \%$ willingness to pay mie samyang berlabel halal LPPOM MUI dipengaruhi oleh pendapatan, pengalaman mengkonsumsi, dan kesadaran kehalalan. Sedangkan sisanya yaitu 41,1\% dipengaruhi oleh variabel lain yang tidak diteliti dalam penelitian ini.

\section{Pengaruh Pendapatan terhadap Willingness to Pay Mie Samyang Berlabel Halal LPPOM MUI}

Pengujian pengaruh pendapatan terhadap willingness to pay mie samyang berlabel halal LPPOM MUI menghasilkan nilai signifikansi kurang dari 0,05 yaitu 0,000, maka hipotesis yang 
berbunyi "pendapatan berpengaruh terhadap willingness to pay mie samyang berlabel halal LPPOM MUI" diterima. Hasil penellitian ini sejalan dengan pendapat Soekartawi dalam buku berjudul "Faktor-faktor Produksi" yaitu pendapatan akan mempengaruhi banyaknya barang yang dikonsumsi. Bertambahnya pendapatan akan menyebabkan barang yang dikonsumsi bertambah. Bukan hanya penambahan barang yang dikonsumsi, namun kualitas barang yang dikonsumsi pun juga menjadi perhatian. Oleh karena itu, semakin tinggi pendapatan maka akan semakin tinggi pula willingness to pay untuk mendapatkan produk berkualitas seperti mie samyang berlabel halal LPPOM MUI.

Hasil penelitian ini menunjukkan 67 responden berpendapatan rendah (di bawah $\mathrm{Rp}$ 925.000,00) mayoritas bersedia membayar mie samyang berlabel halal LPPOM MUI di bawah Rp 25.000,00 dan 29 responden berpendapatan tinggi (lebih dari atau sama dengan Rp 925.000,00) mayoritas bersedia membayar mie samyang berlabel halal LPPOM MUI lebih dari atau sama dengan Rp 25.000,00. Pada penelitian Putri (2016) dalam skripsinya yang berjudul "Analisis Willingness to Pay Konsumen terhadap Daging Ayam Ras Bersertifikat Halal" juga menunjukkan bahwa pendapatan berpengaruh terhadap willingness to pay.

\section{Pengaruh Pengalaman Mengkonsumsi terhadap Willingness to Pay Mie Samyang Berlabel Halal LPPOM MUI}

Pengujian pengaruh pengalaman mengkonsumsi terhadap willingness to pay mie samyang berlabel halal LPPOM MUI menghasilkan nilai signifikansi kurang dari 0,05 yaitu 0,014, maka hipotesis yang berbunyi "pengalaman mengkonsumsi berpengaruh terhadap willingness to pay mie samyang berlabel halal LPPOM MUI" diterima. Hasil penellitian ini sejalan dengan pendapat Mowen dan Minor (2002) dalam buku berjudul "Perilaku Konsumen Jilid 1 Edisi Kelima" yaitu pengalaman berpengaruh terhadap keputusan konsumen. Pengalaman yang positif dan cenderung puas akan berdampak pada sikap yang positif dan mengarah pada pembelian ulang dan sebaliknya bila pengalaman konsumen bersifat negatif maka akan berdampak negatif pada sikap. Pada penelitian ini, 68 orang responden yang pernah mengkonsumsi mie samyang bersedia membayar lebih untuk mie samyang berlabel halal LPPOM MUI. Jadi, pengalaman mengkonsumsi dapat berpengaruh signifikan terhadap willingness to pay karena konsumen mendapatkan pengalaman yang positif ketika mengkonsumsi mie samyang.

\section{Pengaruh Kesadaran Kehalalan terhadap Willingness to Pay Mie Samyang Berlabel Halal LPPOM MUI}

Pengujian pengaruh kesadaran kehalalan terhadap willingness to pay mie samyang berlabel halal LPPOM MUI menghasilkan nilai signifikansi kurang dari 0,05 yaitu 0,030, maka hipotesis yang berbunyi "kesadaran kehalalan berpengaruh terhadap willingness to pay mie samyang berlabel halal LPPOM MUI" diterima. Hasil penelitian ini menunjukkan 37 responden dengan kesadaran kehalalan tinggi (lebih dari atau sama dengan 50) dan pendapatan rendah (kurang dari $\mathrm{Rp}$ $925.000,00$ ) bersedia membayar dibawah $\mathrm{Rp} 25.000,00$. Hal ini menunjukkan walaupun responden memiliki kesadaran kehalalan tinggi namun pendapatan atau uang saku per bulan rendah maka besaran nilai kesediaan membayarnya juga akan rendah. Sedangkan dalam penelitian lain yang dilakukan oleh Putri (2016) dalam skripsinya yang berjudul "Analisis Willingness to Pay Konsumen terhadap Daging Ayam Ras Bersertifikat Halal" menunjukkan bahwa kesadaran kehalalan berpengaruh terhadap willingness to pay. 


\section{Pengaruh Pendapatan, Pengalaman Mengkonsumsi, dan Kesadaran Kehalalan Secara Simultan terhadap Willingness to Pay Mie Samyang Berlabel Halal LPPOM MUI}

Hasil penelitian menunjukkan bahwa terdapat pengaruh signifikan dari variabel pendapatan, pengalaman mengkonsumsi, dan kesadaran kehalalan secara bersama-sama terhadap willingness to pay mie samyang berlabel halal LPPOM MUI. Hal ini ditunjukkan dengan hasil pengujian dengan uji $F$ yang diperoleh yaitu sebesar 43,921 dengan nilai signifikansi $F$ sebesar $0,000<0,050$ yang berarti pendapatan, pengalaman mengkonsumsi, dan kesadaran kehalalan secara bersama-sama memiliki pengaruh terhadap willingness to pay mie samyang berlabel halal LPPOM MUI.

\section{SIMPULAN}

Hasil penelitian menunjukkan bahwa secara parsial maupun simultan variabel pendapatan (uang saku per bulan), pengalaman mengkonsumsi, dan kesadaran kehalalan berpengaruh secara signifikan terhadap willingness to pay mie samyang berlabel halal LPPOM MUI. Dari 96 orang responden, 39 orang bersedia membayar mie samyang berlabel halal LPPOM MUI dengan harga $\mathrm{Rp} 15.000,00$. Oleh karena ketiga variabel berpengaruh secara signifikan, maka kedepannya diharapkan Pemerintah dan Perusahaan mie samyang dapat memperhatikan produk mie samyang yang beredar di masyarakat agar konsumen mendapatkan keamanan, kenyamanan, dan keselamatan dalam mengkonsumsi. Selain itu, Pemerintah melalui institusi terkait dapat memberikan sosialisasi mengenai produk mie samyang halal agar masyarakat tidak ragu untuk membayar lebih pada produk mie samyang berlabel halal LPPOM MUI.

Terdapat banyak faktor yang dapat mempengaruhi willingness to pay mie samyang berlabel halal LPPOM MUI yang masih belum diteliti dan dikaji pada penelitian ini. Oleh karena itu, penelitian ini dapat dikembangkan lagi dengan memasukkan variabel-variabel tersebut. Selain itu, penambahan referensi perlu dilakukan untuk mendukung penelitian.

\section{DAFTAR PUSTAKA}

Ekawati, NW. (2012). Jejaring Sosial/Facebook Sebagai Media E-Pengecer (Studi Kasus Mahasiswa di Kota Denpasar). Buletin Studi Ekonomi, 17 (2):1-6.

Fauzi, A. (2004). Ekonomi Sumber Daya Alam dan Lingkungan. Jakarta: PT Gramedia Pustaka Utama.

Kamaruddin, et al. (2012). Willingness to Pay for Halal Logistics: The lifestyle choice. Jurnal Procedia Social and Behavioral Science, 722-729.

Mowen, J.C dan Minor, M. 2002. Perilaku Konsumen Jilid 1 Edisi Kelima (Terjemahan). Jakarta: Erlangga.

Muhson, A. (2016). Pedoman Praktikum Analisis Statistik. Fakultas Ekonomi Universitas Negeri Yogyakarta.

Nuriana, W. D. (2014). Analisis Willingness to Pay terhadap Sertifikasi Halal Produk Kosmetik Wardah pada Dua Lokasi Penjualan di Bogor. Skripsi. Institut Pertanian Bogor.

Putri, W. R. (2016). Analisis Willingnes to Pay Konsumen terhadap Daging Ayam Ras Bersertifikat Halal (Studi Pada Pendurungan Kota Semarang). Skripsi. Universitas Diponegoro Semarang. 